\title{
Treatment of chronic low back pain with postural sagittal brace (LORDACTIV)
}

\author{
Jean-Francois Salmochi, Jean-Claude De Mauroy, P Vallese, P Rougier, F Munoz, P Fouën \\ From 7th International Conference on Conservative Management of Spinal Deformities \\ Montreal, Canada. 20-22 May 2010
}

\section{Introduction}

In the common back pain, the need to limit the discovertebral constraints without restrict the activities of the patient led to realization for a brace of serial actions targeted on the sagittal balance : rétroposition of trunk, limitation of flexion of the spine, maintaining lordosis without constraints on the facet joints; the 4 clinical studies and experiments presented confirm the usefulness of this approach.

\section{Objectives}

The validation, for a brace of rétropositionnement trunk with maintained lordosis (LORDACTIV), is clinical, rachimétric, radiological, and postural.

\section{Materials and methods}

- Clinic: 113 chronic low back pain with degenerative discopathy $(56 \mathrm{~F} / 57 \mathrm{H})$, in average since 8 months, average age 42, wearing the brace $8 \mathrm{~h}$ per day for 1 month.

- Rachimétric: flexion of the spine in 39 diseases lumbars degeneratives with and without orthotics.

- Posturologic: 11 degenerative disc disease on force platform with and without orthosis.

- Radiologic: 4 cases with study of pelvic sagittal parameters with and without orthosis.

\section{Results}

- Clinic: mean decrease of the VAS in 4 weeks: $80 \%$.

- Rachimétric : flexion average restriction of the spine: $63 \%$.

- Posturologic : reduction the distance traveled by the center of gravity in the anteroposterior axis : 66\%; reduction of the time correction of center of gravity in the anteroposterior axis : $23 \%$.

Clinique du Parc, Lyon, France

Full list of author information is available at the end of the article
- Radiographic : Coherence of the sacral slope and of the lordosis with theangle of pelvic incidence.

\section{Discussion and conclusion}

These results confirm the importance of balance sagittal in the lumbar degenerative disease, this justifies a brace limiting flexion of the spine and maintaining the lumbar lordosis, and this action is effectively achieved with the orthosis "LORDACTIV", which allows more business continuity, a fundamental element in the fight against the transition to Chronicity.

Published: 10 September 2010

doi:10.1186/1748-7161-5-S1-064

Cite this article as: Salmochi et al:: Treatment of chronic low back pain with postural sagittal brace (LORDACTIV). Scoliosis 2010 5(Suppl 1):O64.
Submit your next manuscript to BioMed Central and take full advantage of:

- Convenient online submission

- Thorough peer review

- No space constraints or color figure charges

- Immediate publication on acceptance

- Inclusion in PubMed, CAS, Scopus and Google Scholar

- Research which is freely available for redistribution

Submit your manuscript at www.biomedcentral.com/submit
C Biomed Central 